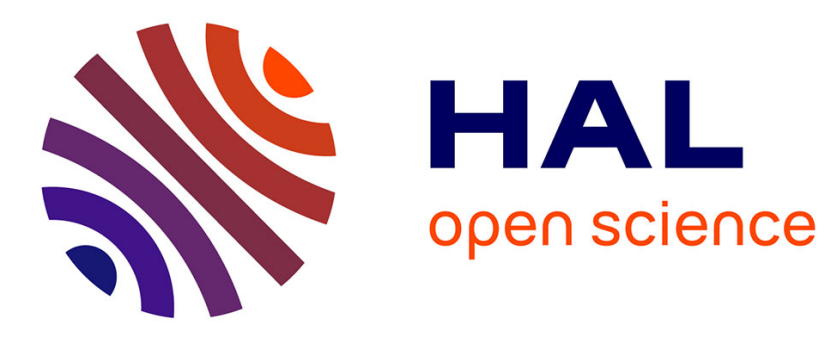

\title{
Material Culture Studies and Ethnocultural Identity
}

\author{
Bernard Sellato
}

\section{To cite this version:}

Bernard Sellato. Material Culture Studies and Ethnocultural Identity. Victor T. King; Zawawi Ibrahim; Noor Hasharina Hassan. Borneo Studies in History, Society and Culture, 4, Universiti Brunei Darussalam, Institute of Asian Studies; Springer Publications, pp.57-78, 2017, IAS Asia in Transition Series, 978-981-10-0671-5. 10.1007/978-981-10-0672-2_4 . hal-02883153

\section{HAL Id: hal-02883153 \\ https://hal.science/hal-02883153}

Submitted on 28 Jun 2020

HAL is a multi-disciplinary open access archive for the deposit and dissemination of scientific research documents, whether they are published or not. The documents may come from teaching and research institutions in France or abroad, or from public or private research centers.
L'archive ouverte pluridisciplinaire HAL, est destinée au dépôt et à la diffusion de documents scientifiques de niveau recherche, publiés ou non, émanant des établissements d'enseignement et de recherche français ou étrangers, des laboratoires publics ou privés. 
Material Culture Studies and Ethnocultural Identity

\title{
Bernard Sellato
}

\begin{abstract}
This chapter briefly exposes the changing focuses of material culture studies through the twentieth century. It then assesses the available corpus of studies in Borneo's material culture, proposing a rough periodisation of the types of publications and describing in broad categories the material productions examined in these publications. Finally, using some examples, it endeavours to shed light on the linkages between material culture, on the one hand, and social relations and ethnocultural identity, on the other.
\end{abstract}

Keywords: Borneo, Material culture, Ethnocultural identity, Social relations, Trade

\section{Material Culture and Material Culture Studies}

Material culture, a phrase that appeared in the social sciences in the late nineteenth and early twentieth centuries, remained centred on the artefact per se up to the latter part of the twentieth century, and material culture studies were then primarily descriptive. Artefacts were (or had been) collected by explorers, colonial civil administrators or military personnel, geologists or missionaries, and stored in museums. Important studies were produced by museum curators, scholars working with museum collections and knowledgeable compilers, though often with only scant information available on the artefacts' precise geographic and ethnic origins, vernacular names, functions, or their meaning and cultural relevance among the people who produced them. While such collections and studies remain precious assets, they provide little insight into those peoples' social lives.

The concept of material culture today covers a much broader scope, concerned as it is with the forms, uses and meanings of objects, images and environments in everyday life. Material culture is the product of the interaction of people and their material world, and one means by which culture is stored and transmitted. An artefact, therefore, can no longer be reduced to the status of a 'thing'. It is, in an important way, a social rather than individual creation and, therefore, material culture as a whole reflects the conceptual context of a society. Artefacts intervene in the construction of society and of social identities (see Journal of Material Culture). Moreover, as fully fledged constitutive elements of social life they also have a social life of their own (Appadurai 1986), through the process of their creation and their use (Lemonnier 1992), hence the need to view objects as agents (Gell 1998). Material culture, therefore, must be examined with the purpose of procuring an understanding of the society that created it.

Material culture studies - now an interdisciplinary field including anthropology, sociology, archaeology, art history and museum studies - are concerned with the social, cultural, economic and symbolic context of artefacts, and thus with the linkage between these and social relations in general, and investigate the ways in which material objects participate in socialising people into culture. In short, the craftsperson 'weaves the world' in everything s/he does, and by doing so s/he 
'makes culture' (see Ingold 2000).

Actually, such studies do encompass other fields, such as environmental studies (landscapes, fauna and flora), agronomy (land tenure systems, cultigens), technology (e.g. architecture, weaponry), cognition science (indigenous knowledge, transmission), health sciences (ethnomedicine, traditional pharmacopoeia), and religion and rituals (e.g. shamanism, headhunting). Despite their name, they are also found to cover such 'immaterial' aspects of culture as oral history, oral literature, dance and music performance, as per the broader concept of 'cultural heritage' (as defined by UNESCO's 1972 World Heritage Convention; see also the concept of 'cultural property' as a basic tenet of people's identity, as recalled in a 1976 UNESCO recommendation; on the ambiguity in the definition of the so-called 'immaterial heritage' see Bromberger 2014). Today, material culture studies are also, for a substantial part, focusing on contemporary 'cultural change' in the context of globalisation, as well as on the subject of 'development' (on Borneo see, for example, Cleary and Eaton 1992; on material culture change see Regis 1996).

In the course of time, scholars have used a variety of approaches to look at material culture - functionalism, structuralism, symbolism, gender studies, consumerism, etc. (see a review in Davy Ball 2009). In the closing decades of the twentieth century the focus in anthropology shifted towards technological processes and again, more recently, away from the object itself and towards social and cognitive processes.

Due to constraints I shall not try to assess the available corpus of studies in Borneo's material culture in terms of theoretical approaches or disciplinary fields. Instead, I shall attempt, first, to establish a rough periodisation of the types of publications and describe in broad categories the local material productions examined in these publications; and, second, using examples, to shed light on the linkages between material culture, on the one hand, and social relations and ethnocultural identity, on the other.

\section{Material Culture Studies in the Literature on Borneo}

A number of early accounts of Borneo-for example, Marryat (1848), Schwaner (1853-54), Veth (1854-56), St John (1862), Perelaer (1870), Bock (1882), Whitehead (1893) or Beccari (1904) — do contain information on material culture, though they generally are framed in a narrative format.

Around the turn of the twentieth century Beccari (1904: 365, cited in Leibrick 1989) was already urging for 'the comprehensive and detailed documentation of the minutiae of Sarawak's indigenous material culture heritage'. Indeed, at that time substantial pieces of work began to appear. These were rather general, synthetic accounts by explorers (e.g. Nieuwenhuis 1904-7) or colonial administrators (e.g. Enthoven 1903; Hose and McDougall 1912), museum inventories and catalogues (e.g. van der Chijs 1885 in Batavia, Shelford 1904-5 at the Sarawak Museum, Juynboll 1910 in Leiden), or compilations produced back in the West (e.g. Hein 1890; Roth 1896), most of which remain invaluable sources to this day. In the same period, more focused, albeit sometimes notably shorter, studies were published, in which scholars investigated the uses and meanings of things: Dayak pictorial and 
technical arts (Hein 1889), bamboo ornaments (Loebèr 1903), costume (Tromp 1890), tattoo patterns (Den Hamer 1885; Hose and Shelford 1906), swords (Tromp 1888; Shelford 1901), offering structures and funerary monuments (Grabowsky 1888, 1889), musical instruments (Grabowsky 1905) and decorative motifs (Haddon 1905).

The period between the two world wars saw a relatively limited output of important 'ethnographic' books - Elshout (1926) and Tillema (1938) on Apo Kayan, Evans (1922) and Rutter (1929) on Sabah, Lumholtz (1920) on the southern and central regions (some of which were reprinted in the 1980s and 1990s) - and a noteworthy development of generally shorter pieces covering, with a narrower focus, a broader scope of material productions. Apart from Bornean arts (Nieuwenhuis 1925-26), tattoos (Tillema 1930), decorated bamboo (Loebèr 1918-19), funerary monuments (Ten Cate 1922; Bertling 1927-28; Tillema 1931-32) and decorative motifs (Vroklage 1939), new attention was brought to masks (Rassers 1928-29; Tillema 1937; Schärer 1940-41), textiles (Haddon and Start 1936), ornamented shields (Münsterberger 1939), basketry (Woolley 1929; Tillema 1939), woodcarving (Banks 1941), bronze works (Huyser 1929; Tillmann 1939) and megalithic monuments (Banks 1937). Most such pieces appeared in scholarly journals, both Dutch and British, as well as in the Sarawak Museum Journal (from 1911 onwards), though some were released in wider audience journals or magazines in the Netherlands, thus contributing to the general public's interest in Borneo cultures.

In-depth professional anthropological work started in Sarawak in the early 1950s with social-economic surveys commissioned by the British colonial service (Leach 1950; Needham 1953; Morris 1953; Geddes 1954; Freeman 1955). In these studies, material culture does not feature prominently, as their authors, social anthropologists, seem to almost never have considered it per se, or described and studied it in an ethnographic way, but instead viewed it only as the physical provision for, or medium of, otherwise important social or economic activity.

This trend persisted during the second half of the century in British and American scholarly studies (e.g. PhD dissertations), with scholars often devoting only minor side papers to material culture topics. By the century's closing decade, the Borneo Research Council's (BRC) publications (Monograph Series, Proceedings Series, etc.), with few exceptions, had focused on gender, religion, shamanism, headhunting, land tenure, social control, health, language, development and the environment, and only a relatively small percentage of the articles published in the Borneo Research Bulletin were devoted to material culture. However, the $\mathrm{BRC}$ is now scheduling several books on material culture for publication.

During that period, a limited number of works dealt, in a more or less general way, with Borneo's material culture and art (Gill 1968; Brenan 1975; Avé 1982; Heppell 1988, 1994, 2005a; Mashman 1989; Kurui and Kaboy 1989; Sellato 1989, 1992; Tillotson 1994), handicrafts (Alman 1963, 1968; Zainie 1969; Morrison 1972, 1982; Munan 1989a, b; Piper 1992), decorative motifs, design, style and art history (von Heine-Geldern 1966; McBain 1981a; Anggat 1988). Few of these, however, are full-length books or academic productions.

To this day, $\mathrm{PhD}$ dissertations in the social sciences focusing, at least partly, on 
material culture have usually only appeared fairly recently and are still uncommon (e.g. Dunkel 1975; Béguet 1993; Tillotson 1994; Gavin 1995; Thambiah 1995; Lindell 2000; Oley 2001; Westmacott 2002; Davy Ball 2009) —if we set aside a few studies concerned with imported ceramics (B. Harrisson 1984; Césard 2009).

While large exhibitions of Indonesian arts held in the Netherlands and the United States (e.g. see Chicago 1948; van Brakel et al. 1987; Taylor and Aragon 1991; Capistrano-Baker 1994; van Brakel et al. 1996) sometimes included a sizable section on Borneo, exhibitions specifically devoted to Borneo have been few and, likewise, their catalogues (e.g. Anonymous 1973; Avé and King 1986; Expedition 1988). In the last few years, however, Borneo has received more sustained attention: Maiullari and Arneld (2008), Maiullari (2011), Isler and von Wyss-Giacosa (2011), Dietrich and Pavaloi (2013), and the 2013 joint Dutch-Bruneian exhibition in Bandar Seri Begawan should also be mentioned (see KIT 2013). Scholars in Western museums produced studies based on these museums' collections: e.g. Sørensen (1972, 1973) in Oslo, Hamilton (1996) in Washington (see also Boruchoff 1986), Remešová (2004) in Prague, Martin (2010) in Dresden. Several Borneo exhibitions in art galleries were complemented with catalogues (e.g. Goldman 1975; Heppell and Maxwell 1990; Heppell 1992; Johnson 2009).

In East Malaysia, the Sarawak Museum produced an important book (Chin 1980), as well as a number of thin booklets on various subjects, and the Sabah Museum later followed suit (e.g. Sabah 1991, 1992, 2007, n.d.). Likewise, the Brunei Museum has put out some publications on material culture (e.g. Harrisson 1973; Warisan 1996; Bantong 2001). Through their periodic journals, these three institutions have also contributed powerfully to expanding our knowledge of northern Borneo's cultures in general.

Other publications were released in Kuching by the Borneo Literature Bureau (e.g. Alman 1968; Zainie 1969) and the Sarawak Literary Society (e.g. Chong 1987; Bléhaut 1997) and, in Kuala Lumpur, by Dewan Bahasa dan Pustaka (e.g. Anggat 1988) and the Museum Association of Malaysia (e.g. Mohd. Kassim 1983). In Sarawak, private publishers, the Tun Jugah Foundation and Society Atelier Sarawak, released several important titles that should be mentioned: Linggi (2001) and Sultive and Sutlive (2001), for the former, and Jabu (1991), Chin and Mashman (1991) and Ong (n.d.) for the latter.

In Indonesia nationwide programmes (proyek) implemented by the Ministry of Education and Culture in the 1980s and 1990s_-variously named Proyek Media Kebudayaan, Proyek Inventarisasi dan Dokumentasi Kebudayaan Daerah, Proyek Inventarisasi dan Pembinaan Nilai-nilai Budaya or Proyek Pembinaan Permuseuman - underwrote the publication of series on the collections held by provincial museums (e.g. Album seni budaya, Sekelumit 1989-90; Syarifuddin and M. Saperi 1990-91; Magai 1991; Rasmin et al. 1992-93), traditional architecture (Soenarpo et al. 1986), and many more on various material culture topics (e.g. Anonymous 1982; Surya et al. 1985-86; Husna et al. 1990-91; Taihuttu 1995-96). Kalimantan's state museums also occasionally published thematic volumes on their collections (e.g. Sjarifuddin 1983-84; Bonoh 1984-85; Achmad 1986; Mulyati and Zularfi 1994; see also Kartiwa 1997). Unfortunately, these publications are poorly disseminated and quite difficult to procure, and keeping up to date with recent 
releases proves a real challenge.

Finally, a few photographic books (e.g. Morrison 1962; Wong 1979; Hong 1987; Tiong 2001) have documented traditional life, thus providing much visual information on material culture.

Altogether, in the latter part of the twentieth century and up to this day a wealth of information has been produced. A review of these publications by broad thematic categories is presented below.

By far the most popular research and publication topic in material culture studies in the last three decades has been textiles, and especially Iban textiles. Initiated by Haddon and Start's (1936) book, work on Iban (and Kalimantan 'Ibanic') woven fabrics picked up again around 1980 (Fisher 1979; Maxwell 1980; Vogelsanger 1980), then went into full swing 10 years later (Drake 1991; Jabu 1991; Mashman 1992; Gavin 1995, 1996, 2003; Linggi 2001; Heppell 2005b, 2014; Amann 2013), albeit not always exempt of some debate regarding the ambiguous relationship of motif, name and meaning. Apart from the Iban-Ibanic set, we should mention some work on Sabah's traditional weaving and dyeing (Sabah 1991), Brunei textiles (Warisan 1996) and East Kalimantan's unusual ulap doyo textiles (Oley 2001, 2007).

The longhouse has also been a popular focus of study, although only some of the works discuss architecture and/or the longhouse as a physical structure (e.g. Lee 1962; Miles 1964; Schneeberger 1979; Kelbling 1983; Kampffmeyer 1991; Ong 1991; Winzeler 1996, 1998, 2004; Lindell 2000). Other works mainly examined the longhouse as a social institution, a ritual structure or a symbolic element of identity (Dove 1982; Guerreiro 1984, 2003; Sather 1993; Alexander 1993; Sellato 1998, 2015a; Metcalf 2010), in an 'anthropology of architecture' approach, as Waterson's (1990) book title stresses - or as a target for the ethnic tourism industry (Kruse 2003; also King 1994; Zeppel 1994).

Woodcarving, especially in hardwood, holds a special status in material culture, due to primitive art dealers' and collectors' sustained interest in Borneo's sculpture, starting with Vredenbregt's booklet (1981). Large carved pieces were regarded as art, and museums and art galleries published book-sized catalogues on the subject (e.g. Sumnik-Dekovich 1985; Heppell and Maxwell 1990; Maiullari and Arneld 2008; Johnson 2009), while some isolated articles appeared in journals (Chong 1987; Mashman 1994; Kjellgren 1999; Sellato 2001; but see also Chin and Mashman 1991). Shorter studies focused on carved funerary monuments (e.g. Bataille 1974; Metcalf 1976; Rampai 1983; Schiller 1984; Guerreiro 2011). Related to the statuary, due to the primitive art market's interest, are masks, which were also the subject of several publications: Gill (1966, 1967), Revel-Macdonald (1978, 1981), Mohd. Kassim (1983), Heppell (1992, 2015) and Bantong 2001.

With pottery and basketry, we leave the world of 'primitive art' for that of 'folk crafts'. Both crafts have seen a trickle of mostly minor publications spanning half a century. For pottery: Freeman (1957), Alman (1960), Anonymous (1985), Chin and Mashman (1991), Sellato (1997), Teuteberg (1998), and Arifin and Sellato (1999). For basketry: Klausen (1957), Dunsmore (1983), Bléhaut (1997), Sellato (1997, 2012d), Lenjau (1999), Maiullari (2011) and Puri (2013). 
Other, slightly less 'popular' categories must be mentioned: metalware (including swords) and metalworking (e.g. Morrison 1948; Harrisson 1973; Lim and Shariffuddin 1976; Christie and King 1988; Chin and Mashman 1991; Heppell 2011; Hollestelle forthcoming); megalithic monuments (e.g. Harrisson 1958; Whittier and Whittier 1974; Baier 1992; Arifin and Sellato 2003); tattoos (Dunkel 1975; Thomas 1968; McBain 1981b); decorated human skulls (Avé 1996; Winzeler 1999); wooden 'calendars' (Avé 1970; Hopes 1997); baby carriers (Whittier and Whittier 1988; Sellato 2012b); bark cloth (Kooijman 1963; Sellato 2006); to which we may add traditional 'sports' (e.g. Anonymous 1982; Dunsmore 1983; Chin 1984), penis pins (Harrisson 1964; Brown et al. 1988), bamboo tubes (Klokke 1993), longboat building (Nicolaisen and Damgaard-Sörensen 1991), hunting weapons and traps (Sloan 1975; Puri 2006), and even, once in a while, local traditional cuisine (Jamuh and Harrisson 1966-69; Dirung and Dirung 1993).

We could also include here works on music and dance (e.g. Seeler 1969; Maceda 1978; Matusky 1986, 1990, 1991; Gorlinsky 1988; Pugh-Kitingan 1988), as well as on crucial, though exogenous, elements of the Bornean material culture: glass beads (Dunsmore 1978; Munan-Oettli 1987; Munan 2005) and ceramic jars (Adhyatman and Abu Ridho 1977; B. Harrisson 1986; Rangkuti and Faizaliskandiar 1988; Wibisono 1990; Sabah 2007; Césard 2009).

Finally, I shall leave aside very recent works focusing on contemporary cultural change and dealing with topics outside of my sphere of expertise, although some should probably be listed in this chapter, such as Liana Chua's studies.

\section{Material Culture and Ethnocultural Identity}

In a recent paper, Victor T. King (2012) examined 'the interrelated concepts of culture and identity, and more especially identities in motion'. Artefacts, of course, often display visual evidence of ethnocultural affiliation.

As already noted, locally crafted objects, present everywhere in traditional societies to fulfil all sorts of practical, daily life functions, also pervade the social, economic, political and religious spheres. They are involved in sharing and exchange networks, feature prominently as symbols of social status and prestige, and perform primary roles in ritual activities, and thus they are constitutive elements of social life, and strongly contribute to building and upholding ethnocultural identity.

The discussion below, intentionally focusing on 'traditional' artefacts of local commercial, social or ritual significance - rather than on recently appropriated 'modern' objects - attempts to investigate, among the communities that produce them, their evolution into new icons of identity — or 'icons of tradition', as Taylor (1994) puts it — in a wide open and fast-changing world.

\subsection{The Bidayuh Red Basket}

A good example of this evolution is presented by Mashman and Nayoi (2012) with the so-called 'red basket' of the Pinyawa'a subgroup of Bidayuh in western 
Sarawak. Traditionally, this red basket (juah bireh) was used for sowing and harvesting, as well as in rituals of the paddy cult (adat gawai), particularly at harvest time, as a container for offerings to the rice spirits; it also features in traditional marriage exchanges (ibid.:89). However, '[i]n its most profound context', the authors write, the red basket is used for supernatural purposes during the healing ceremonies, with each household owning one; here called 'soul basket', it is a container for the soul of a sick person (ibid.:80, 91).

In the 1960s a Catholic mission and school were set up at a nearby bazaar, and most of the community have since converted (ibid.:81). The red basket is now put to mundane use - for carrying personal belongings around — but '[i]t is most publicly conspicuous at the weekly church service, when it serves for the collection' (ibid.:89). Interestingly, it is now used by both Catholics and practitioners of the paddy cult in shared rituals and celebrations: Catholic families partake in the paddy cult rituals, using their own red baskets and saying Catholic prayers, and non-Catholics also attend a thanksgiving ceremony held at the church, during which young women in ethnic costumes, carrying red baskets, 'dance around the altar to the beat of the gongs in a manner reminiscent of the priestesses who dance to entertain the spirits of the rice' (ibid.:91).

Later, in the 1970s, a strong movement within the Bidayuh community aimed at popularising ritual dances for public performances, and encouraged younger Catholic women to practise them (ibid.:92). The women's new ethnic costume, partly deriving from the priestess's dress, includes the red basket, along with the typical raong hat, which was worn to protect a baby's soul. This costume is worn for dancing contests, ceremonial occasions and special masses in church.

Both the hat and basket, now as an inseparable pair, have thus become key components in the Pinyawa'a community's ethnocultural identity (ibid.:80-81, 92). If 'the red basket provides a sense of cultural continuity as the belief systems change' from the traditional adat gawai to Christianity, as Mashman and Nayoi rightly noted (ibid.:89; see also Mashman 2000), the iconic value of the hat-and-basket pair, and of this Bidayuh ethnic costume as a whole, has now spread out to the social and political sphere beyond the community, and to Sarawak's cultural stage.

In a similar process, among the Lun Dayeh (or Lundaye) of North Kalimantan (the new Indonesian province of Kalimantan Utara) and the Lun Bawang and Kelabit of Sarawak (with some degree of variation between these groups), the ritual raung basung (or rong) hat and tayen (or ra'ing) basket were originally used for sowing and harvesting, and appeared in rice cycle rituals, as well as in traditional marriage exchanges. Nowadays, the hat-and-basket pair is mostly manufactured and sold for use in Christian wedding ceremonies, which still rally broad kinship networks, even in town (Mashman 2012: 180-181; see Davy Ball 2009: 365; Sellato 2012a).

Among the eastern Sarawak Lun Bawang, Mashman (2012: 181) concludes, these hats and baskets are now worn as part of the ethnic costume at weddings and formal occasions as a mark of identity. Likewise, Kalimantan Lun Dayeh women, dressed in a standard ethnic costume, perform group dances at events such as the 
annual Birau festival at the district's capital and in the course of National Day celebrations, in which the raung and tayen are recognisable ethnic identity icons (Sellato fieldnotes).

\subsection{The Kenyah Baby Carrier}

Among Kenyah, Kayan and related groups, which display distinctive, named and operative social strata (including nobility, commoners and slaves), both in Sarawak and Kalimantan, social ascription and status used to be visually discernible through the exclusive use of certain types of objects and decorative patterns (see, e.g. Rousseau 1990: 186-187; also Whittier 1973; King 1985). The baby carrier, a trademark artefact of these groups, offers a clear example of this, as both the motifs decorating it and small objects attached to it are not only protective devices against spiritual danger (for the child carried in it) but also indicators of social status (for the family owning and using it).

'Functionally analogous to the ... cloth slings used to carry infants by many people around the world' (Whittier and Whittier 1988), the baby carrier is a simple structure built of a half-moon wooden board and raised rattan plaitwork, and is equipped with shoulder straps. Its decoration is what makes it spiritually and socially significant: a large beadwork panel, animal fangs, bronze bells, shells, etc. Baby carriers, particularly their decorative elements, are part of family heirlooms. They are used, associated with a broad, decorated sun hat, in name-giving ceremonies, as well as, among some groups, in weddings and other rituals (see Whittier and Whittier 1988; Sellato 2012b; Lenjau et al. 2012: 217).

Noble families have a strict monopoly on the creation and use of certain decorative motifs and objects to be displayed on a baby carrier (and other items), e.g. anthropomorphic motifs or tiger and leopard fangs (for recent sources, see Armstrong 1992: 203; Lenjau 1999: 174; Lenjau et al. 2012: 219-20, 223; Sellato 1997: 230, 2012b: 272). Among the Kenyah of the uppermost Bahau River, only women of the noble stratum may create the anthropomorphic kalung kelunan or kalung éla' motifs, as only the souls of noble people are strong enough to be exposed to the power of the motif. Yet, the spiritual risk incurred calls for a ritual payment or a blood sacrifice to the spirit of the motif, and such a motif may only be used for children of the noble category (Sellato 1997: 230).

Supernatural sanctions are believed to befall any non-noble person who would be so bold as to make or use an object carrying such a powerful spirit. In the 1990s Lenjau (1999: 171-72) wrote that the Kenyah still carefully heeded this taboo (see also Armstrong 1992: 203). Baby carriers, along with the broad sun hats (sa'ung seling) also carrying anthropomorphic motifs and restricted to nobility (see Sellato 2012c), are usually displayed on house walls. Altogether, as the Whittiers (1988) conclude: 'The ... baby carrier [is] a work of art, a device for protecting a child's health, a display and confirmation of social rank, and a mechanism for creating and strengthening social relations'.

Sun hats have long been, and still are, often requested by and given away to visiting officials (Sellato 1997: 230), and this also holds, albeit less often nowadays, for baby carriers. Indeed, such officials were naturally viewed as foreign 'nobility', 
so the taboo question was never raised. Moreover, since the hat or baby carrier would be owned or used away from the village, this would have no negative spiritual impact on the source community.

In recent years, however, baby carriers have been manufactured by urban Kenyah communities, in Samarinda and elsewhere, and even in certain Kenyah resettlement villages closer to urban centres. These Kenyah craftspeople, whether or not they belong to the nobility, but no longer worrying about spiritual risk, create attractive decorative beadwork panels displaying anthropomorphic motifs. Such baby carriers are now marketed, with no reference to their ritual or social meaning, to airport souvenir shops or 'antique' shops in town. Some Kenyah families in Samarinda, as early as the 1990s, were running a baby carrier cottage industry and flying their goods to Kuching, where they fetched much higher prices. I was told that part was sold to souvenir shops there, and part to well-to-do Sarawak Kenyah, who needed them for rituals or heirlooms.

This, of course, reflects the dissolution of traditional social organisation and the emerging dominance of individualistic values, especially in urban contexts. Yet, this process strongly contributes to promoting the baby carrier as an iconic craft of the Kenyah on the provincial and even the national scenes.

One traditionally typical Kenyah craft, the cloth patchwork sun hat, has spread widely to other ethnic groups and other regions of Borneo, to the extent that it is now viewed as a symbol of a generic 'Dayak' culture and a standard souvenir from Borneo-and no longer a specifically Kenyah icon.

In the upper Bahau region, a development project has set out recently (2013) to assist local Kenyah craftswomen in producing and marketing the sa'ung seling ritual sun hat in order to generate some revenue for these isolated villages. These women, highly concerned with the possible spiritual risk that might ensue, referred the project staff to the subdistrict's customary chief (kepala adat), who granted special permission for commoner women to manufacture sa'ung seling with anthropomorphic figures (Iris Hardy, personal communication). The sa'ung seling is now manufactured and marketed as a specific product of the Kenyah groups of the uppermost Bahau area, and in the process is becoming these groups' ethnic identity icon in broader regional official settings.

\section{Material Culture, Identity Icons and Trade}

For the record, I should stress here the ritual significance, Borneo-wide, of the pair of artefacts comprising a 'container' (a basket or, here, a baby carrier) and a hat (as the container's cover; see several examples, among various groups, in Sellato 2012d). In the Kenyah case, the sun hat and baby carrier pair forms a 'total' protective device, as well as a sort of ritual enclosure, which in other ethnic contexts outside Borneo would often consist of a ritual textile. It should not be unexpected, somehow, that these artefacts, rather than others of lesser ritual value (e.g. the blowpipe), have been turned into icons of identity. The fact that they carry ethnically distinctive decoration is also quite relevant here.

The Bidayuh's red basket and raong hat and the Lun Dayeh's basket-and-hat 
pair, whose ritual roles in farming or other traditional ceremonies have notably faded away, now feature in Christian ceremonies and, quite prominently, in public displays of ethnic identity, illustrating a general historical shift from a traditional religion to Christianity, another, related shift from the religious to a non-religious or mundane sphere, as well as yet another, from internal (intra-community) to external (inter-community) use.

The Kenyah baby carrier (and associated hat) offers an example of broadened practices transgressing the traditional social order. This clearly hints at the progressive crumbling of social stratification and of the nobility's power over its commoners, even in the most old-fashioned, isolated communities. At the same time, it signals the emergence of new, often urban or peri-urban ethnic communities now estranged from erstwhile ritual prohibitions, and displaying individualistic economic behaviours. It also emphasises the repositioning and marketing of these artefacts by their makers as trade goods of a high economic importance - and these goods also happen to carry ethnic identity value.

Therefore, the role of trade in the promotion of such icons of ethnic identity, if not in their original construction, should not be underestimated. The Lun Dayeh hats and baskets are made mainly for intra-community circulation and sale, although they are also marketed to souvenir shops, which probably also applies to the Bidayuh hat and basket. The Kenyah baby carrier, although it is to some extent circulated among Kenyah groups scattered in various parts of Borneo, appears to mainly target the tourist trade. And the sa'ung seling case illustrates an interesting, ongoing speedy swing from social status marker to trade good to identity icon-the acceleration of the process being a sign of the times.

As the discovery and confirmation of these objects' trade value outside the communities that use/d them - especially in the tourist trade networks - trigger an intensification of their production, they certainly also contribute to boosting their value as ethnic identity icons within these communities (for a discussion of the impact of trade on material culture change, see Sellato 2015b). The tourist trade, in turn, promotes these icons among other regional ethnic groups, as well as to the national scene and beyond.

With regards to trade, the role of external agents - running or supporting local economic development projects, e.g. non-governmental organisations or foundations, state agencies - in the creation and promotion of iconic artefacts is also of relevance and should be taken into account, as is the case for Penan communities' rattan baskets in Sarawak or for the sa'ung seling of the Kenyah in East Kalimantan. Indeed, the advent of iconic objects may not always be a spontaneous endogenous process.

Finally, the question of cultural property should be raised regarding iconic material culture items. The commercial takeover of one group's specific traditional artefacts by another group has become a familiar occurrence, even in Borneo (e.g. the 'tree of life' rattan mat of the Ngaju made by Banjarese, or fake Bahau statues sold by Bugis in Samarinda). And 'iconic takeover' - one group's specific traditional artefact being selected by another group as its own iconic object-is not unheard of (e.g. Sellato 2015b). More generally, the patenting of particular items of 
material culture, as well as of decorative motifs, is now a pending problem in Borneo, as elsewhere. A recent controversy around the bidai mat of the Seluas people of West Kalimantan being claimed by (and patented in) Malaysia as an iconic product of Sarawak (Okezone 2013) is telling enough, as are earlier and ongoing 'cultural' debates between Indonesia and Malaysia about 'ownership' of batik and the shadow puppet theatre (Jakarta Post 2012).

\section{References}

Achmad Maulana. 1986. Seni kerajinan tradisional daerah Kutai. Tenggarong: Museum Negeri Mulawarman, Propinsi Kalimantan Timur.

Adhyatman, S., and Abu Ridho. 1984 [1977]. Tempayan di Indonesia [Martavans in Indonesia]. Jakarta: Ceramic Society of Indonesia (Himpunan Keramik Indonesia).

Album Seni Budaya (or Album Sejarah Seni Budaya). n.d. [1980s]. [A series of illustrated cultural albums for each of the Indonesian provinces]. Jakarta: Departemen Pendidikan dan

Kebudayaan, Proyek Media Kebudayaan.

Alexander, Jennifer. 1993. The Lahanan longhouse. In Inside Austronesian houses. Perspectives on domestic designs for living, ed. J.J. Fox, 30-43. Canberra: Australian National University, Research School of Pacific Studies.

Alman, Elizabeth, and John Alman. 1963. Handcraft in North Borneo. Jesselton: Sabah Publishing House.

Alman, Elizabeth, and John Alman. 1968. Handcraft in Sabah. Kuching: Borneo Literature Bureau.

Alman, John H. 1960. Dusun pottery. Sarawak Museum Journal 9(15/16):565-82.

Amann, Heribert, ed. 2013. Textiles from Borneo: the Iban, Kantu, Ketungau, and Mualang peoples. Milan: 5Continents.

Anggat Ganjing, Augustine. 1988. Basic Iban design: an introduction. Kuala Lumpur: Dewan Bahasa dan Pustaka, Ministry of Education.

Anonymous [S. Dunsmore]. 1985. Iban pottery. Kuching: Sarawak Museum, Occasional Paper 5. Anonymous. 1973. Kalimantan, mythe en kunst: Tentoonstelling van het Indonesisch Ethnographisch Museum, Delft, Februari-December 1973. Introduction by J.B. Avé. Delft: Indonesisch Ethnografisch Museum.

Anonymous. 1982. Olahraga tradisional suku Tunjung 'behempas'. [Tenggarong]: Departemen Pendidikan dan Kebudayaan, Museum Negeri Mulawarman.

Appadurai, Arjun, ed. 1986. The social life of things: commodities in cultural perspective. Cambridge: Cambridge University Press.

Arifin, Karina, and Bernard Sellato. 1999. Gerabah Kalimantan terakhir yang tradisional. Deskripsi ringkas tentang teknologinya. In Kebudayaan dan pelestarian alam. Penelitian interdisipliner di pedalaman Kalimantan, eds. Cristina Eghenter and Bernard Sellato, 523-32. Jakarta: World Wide Fund for Nature.

Arifin, Karina, and Bernard Sellato. 2003. Archaeological survey and research in four districts of interior East Kalimantan. In Social science research and conservation management in interior Borneo: unraveling past and present interactions of people and forests, eds. Cristina Eghenter, Bernard Sellato and G. Simon Devung, 201-41. Jakarta: UNESCO and Center for International Forestry Research.

Armstrong, Rita. 1992. The cultural construction of hierarchy among the Kenyah Badeng. Oceania 62(3):194-206.

Avé, Jan B. 1970. De onbekende bilang kangan der Dajaks. Verre Naasten Naderbij 4(1):3-12, 4 (2):45-53.

Avé, Jan B. 1982. The Dayak of Borneo: their view of life and death and their art. In Art of the archaic Indonesians, ed. W. Stöhr, 93-117. Geneva: Musée d'Art et d'Histoire.

Avé, Jan B. 1996. Bornéo: Les Dayak dans la collection François Coppens. Solutré: Musée Départemental de Préhistoire de Solutré.

Avé, Jan B., and Victor T. King. 1986. Borneo, the people of the weeping forest: tradition and change in Borneo. Leiden: National Museum of Ethnology.

Baier, Martin. 1992. Steinsarkophage und Urnendolmen. Tribus 41:161-175.

Banks, E. 1937. Some megalithic remains from the Kelabit country in Sarawak with some notes on 
the Kelabits themselves. Sarawak Museum Journal 4(15):411-437.

Banks, E. 1941. Sea Dayak carvings. Journal of the Malayan Branch of the Royal Asiatic Society 19(2):220-226.

Bantong bin Antaran. 2001. Topeng kayu Borneo koleksi Muzium-muzium [Wooden masks of Borneo in the Brunei museums collection]. Bandar Seri Begawan: Jabatan Muzium Brunei, Kementerian Kebudayaan, Belia dan Sukan.

Bataille, Marie-Claire. 1974. Sculpture funéraire de Bornéo. Objets et Mondes 14(1):57-62.

Beccari, Odoardo. 1986 [1904]. Wanderings in the great forests of Borneo: travles and researches of a naturalist in Sarawak Singapore: Oxford University Press [first publ. 1904, London:

Archibald Constable].

Béguet, Véronique. 1993. Sama bilik, le pot, le feu, les nattes. Les relations sociales au sein des maisonnées Iban de Bornéo (Sarawak, Malaysia). MA thesis, Université Laval.

Bertling, C.T. 1927-28. Hampatongs of tempatongs van Borneo. Nederlandsch-Indië Oud en Nieuw 12(5):131-141; 12(6):179-192; 12(7):223-236; 12(8):249-254.

Bléhaut, Jean-François. 1997. Iban baskets. Kuching: Sarawak Literary Society.

Bock, Carl. 1985 [1882]. The head hunters of Borneo. Singapore: Oxford University Press [first publ. 1882, London: Sampson Low, Marston, Searle and Rivington].

Bonoh, Yohanes. 1984-85. Seni anyam menganyam anjat suku suku Dayak Banuaq. Tenggarong:

Departemen Pendidikan dan Kebudayaan, Museum Negeri Propinsi Kalimantan Timur

Mulawarman.

Boruchoff, Judith. 1986. Register to the Papers of William Louis Abbott. Washington, DC:

National Anthropological Archives, Smithsonian Institution.

Brakel, J.H. van, David van Duuren, and Itie van Hout. 1996. A passion for Indonesian art: the Georg Tillmann Collection at the Tropenmuseum Amsterdam. Amsterdam: Royal Tropical Institute, Tropenmuseum.

Brakel, J.H. van, et al., eds. 1987. Budaya Indonesia: kunst en cultuur in Indonesië. [Budaya Indonesia: art and culture in Indonesia]. Amsterdam: Tropenmuseum.

Brenan, Astrid. 1975. Tribal art in Borneo and Sarawak. Third-year graphics thesis, Chelsea School of Art, London.

Bromberger, Christian. 2014. Le 'patrimoine immatériel' entre ambiguïtés et overdose. L'Homme 209:143-152.

Brown, Donald E., James W. Edwards, and Ruth P. Moore. 1988. The penis inserts of Southeast Asia: an annotated bibliography with an overview and comparative perspectives. Berkeley: Center for South and Southeast Asia Studies, University of California.

Capistrano-Baker, Florina H. 1994. Art of island Southeast Asia: the Fred and Rita Richman collection in the Metropolitan Museum of Art. New York: Metropolitan Museum of Art.

Cate, W.C. ten. 1922. De doodenpalen in de onderafdeeling Melawi der afdeeling Sintang van de Residentie Westerafdeeling van Borneo. Tijdschrift voor Indische Taal-, Land- en Volkenkunde (Bataviasch Genootschap) 61:201-222.

Césard, N. 2009. Des objets en partage. Produits forestiers, prestations matrimoniales et transformations sociales chez les Punan Tubu, Kalimantan-Est, Indonésie. PhD thesis, École des hautes études en sciences sociales, Paris.

Chicago. 1948. Indonesian art: a loan exhibition from the Royal Indies Institute, Amsterdam, the Netherlands, [to] the Art Institute of Chicago, February 16 to March 31, 1949. Preface by C.T.

Bertling, introduction by R. von Heine-Geldern. New York: Asia Institute.

Chijs, J.A. van der. 1885. Catalogus der ethnologische verzameling van het Bataviaasch

Genootschap van Kunsten en Wetenschappen. Batavia: Albrecht \& Co.

Chin, Lucas, and Valerie Mashman, eds. 1991. Sarawak cultural legacy: a living tradition.

Kuching: Society Atelier Sarawak.

Chin, Lucas. 1980. Cultural heritage of Sarawak. Kuching: Sarawak Museum.

Chin, S.C. 1984. Kenyah tops and top playing, an integral part of the agricultural cycle. Sarawak Museum Journal 33(54):33-53.

Chong Chin Seng. 1987. Traditional Melanau woodcarving (bilum) in Dalat, Sarawak. Kuching:

Sarawak Literary Society.

Christie, J.W., and V.T. King. 1988. Metal-working in Borneo: essays on iron- and silver-working in Sarawak. Hull: Centre for South-East Asian Studies, University of Hull.

Cleary, Mark, and Peter Eaton. 1992. Borneo: change and development. Singapore: Oxford

University Press.

Davy Ball, M. 2009. Betek, tali ngan atap, 'knots, string and blades': production and use of organic utility objects by the Orang Ulu of Sarawak. PhD thesis, University of Durham. 
Dietrich, Stefan, and Margareta Pavaloi, eds. 2013. Flussaufwärts: die Borneo Sammlung Hilde May. Heidelberg: Völkerkundemuseum vPST.

Dirung, S., and M.D. Dirung. 1993. Cara mengawetkan daging dengan daun payang ala Aoheng/Penihing. Gaharu (Samarinda) 3:17-18.

Dove, Michael R. 1982. The myth of the 'communal' longhouse in rural development: the Kantu' of West Kalimantan. In Too rapid rural development: perceptions and perspectives from Southeast Asia, eds. Colin MacAndrews, and Chia Lien Sien, 14-78. Athens: Ohio University Press.

Drake, R.A. 1991. The cultural logic of textile weaving practices among the Ibanic people. In Female and male in Borneo: contributions and challenges to gender studies, ed. Vinson $\mathrm{H}$. Sutlive, 271-293. Williamsburg, VA: Borneo Research Council.

Dunkel, Peter F. 1975. Tatauierung in Borneo. PhD thesis, Freie Universtät Berlin.

Dunsmore, Susi. 1978. Beads. Kuching: Sarawak Museum, Occasional Paper 2.

Dunsmore, Susi. 1983. Sepak raga (takraw): the South East Asian ball game. Kuching: Sarawak Museum, Occasional Paper 4.

Elshout, Jacob M. 1926. De Kenja-Dajaks uit het Apokajan gebied: Bijdragen tot de Kennis von Centraal-Borneo [The Kenyah Dayaks of the Apo Kayan region: contribution to the knowledge of central Borneo]. 's-Gravenhage: Nijhoff.

Enthoven, J.J.K. 1903. Bijdragen tot de geographie van Borneo’s Westerafdeeling. Leiden: Brill, 2 vols.

Evans, Ivor H.N. 1990 [1922]. Among primitive peoples in Borneo. Singapore: Oxford University Press [first publ. 1922, London: Seeley Service \& Co.]. Expedition. 1988. Selections from the exhibition. Special issue on Borneo, Expedition 30(1):3744.

Fisher, Joseph. 1979. Threads of tradition: textiles of Indonesia and Sarawak. Berkeley: Lowie Museum of Anthropology.

Freeman, J.D. 1955. Iban Agriculture: a report on the shifting cultivation of hill rice by the Iban of Sarawak. London: Her Majesty's Stationery Office.

Freeman, J.D. 1957. Iban pottery. Sarawak Museum Journal 8(10):153-176.

Gavin, Traude. 1995. Iban ritual fabrics from Borneo: their patterns and names. PhD thesis, University of Hull.

Gavin, Traude. 1996. The women's warpath: Iban ritual fabrics from Borneo. Los Angeles:

UCLA Fowler Museum of Cultural History.

Gavin, Traude. 2003. Iban ritual textiles. Leiden: KITLV Press.

Geddes, W.R. 1954. The Land Dayaks of Sarawak: a report on a social economic survey of the Land Dayaks of Sarawak presented to the Colonial Social Science Research Council. London: Her Majesty's Stationery Office, Colonial Research Studies 14.

Gell, Alfred. 1998. Art and agency: an anthropological theory. Oxford: Clarendon Press.

Gill, Sarah H.S. 1966. Borneo masks: collected from various European and American museums. MA thesis, Columbia University.

Gill, Sarah H.S. 1967. Style and the demonic image in Dayak masks. Journal of the Malaysian Branch of the Royal Asiatic Society 40(1):78-92.

Gill, Sarah H.S. 1968. Selected aspects of Sarawak art. PhD thesis, Columbia University. Goldman, Philip. 1975. The divine gifts: Dayak sculpture from Kalimantan (Indonesian Borneo). London: Gallery 43.

Gorlinski, Virginia K. 1988. Some insights into the art of sapé' playing. Sarawak Museum Journal 39(60):77-104.

Grabowsky, F. 1888. Ueber verschiedene weniger bekannte Opfergebräuche bei den Oloh Ngadju in Borneo. Internationales Archiv für Ethnographie 1:130-134.

Grabowsky, F. 1889. Der Tod, das Begräbnis, das Tiwah oder Todtenfest und Ideeën über das Jenseits bei de Dajaken. Internationales Archiv für Ethnographie 2:177-204.

Grabowsky, F. 1905. Musikinstrumente der Dajaken SüdostBorneos. Globus 37(7):102-107. Guerreiro, Antonio J. 1984. Min, 'maisons' et organisation sociale: contribution à l'ethnographie des sociétés Modang de Kalimantan-Est, Indonésie. PhD thesis, École des hautes études en sciences sociales, Paris.

Guerreiro, Antonio J. 2003. The Bornean longhouse in historical perspective: social processes and adaptation to changes. In Indonesian houses: tradition and transformation in vernacular architecture, eds. Reimar Schefold, Gaudenz Domenig, and Peter Nas, 283-328. Leiden: KITLV Press.

Guerreiro, Antonio J. 2011. Un poteau blontang exceptionnel au musée du Quai Branly. http:// 
www.origineexpert.com/articles.php?article=AG-BLONTANG.

Haddon, Alfred C., and Laura E. Start. 1982 [1936]. Iban or Sea Dayak fabrics and their patterns:

a descriptive catalogue of the Iban fabrics in the Museum of Archaeology and Ethnology,

Cambridge. Carlton, Bedford: Ruth Bean [first publ. 1936, Cambridge: Cambridge University

Press].

Haddon, Ernest B. 1905. The dog-motive in Bornean art. Journal of the Royal Anthropological Institute 35:113-125.

Hamer, C.J.A. van den. 1885. Iets over het tatoueeren of toetang bij de Biadjoe-stammen in de z/o afd. van Borneo. Tijdschrift voor Indische Taal-, Land- en Volkenkunde (Bataviasch

Genootschap) 30:451-458.

Hamilton, R.W. 1996. The Abbott Collection from Borneo at the National Museum of Natural History, Smithsonian Institution, Washington. Paper presented at the Fourth Biennial International Conference of the Borneo Research Council, Bandar Seri Begawan.

Harrisson, Barbara V. 1984. Pusaka, heirloom jars of Borneo. PhD thesis, Cornell University. Harrisson, Barbara V. 1986. Pusaka: heirloom jars of Borneo. Singapore: Oxford University Press.

Harrisson, Tom. 1958. Megaliths of Central and West Borneo; a living megalithic in upland Borneo. Sarawak Museum Journal 8:394-401, 694-702.

Harrisson, Tom. 1964. The 'palang': its history and proto-history in West Borneo and the Philippines. Journal of the Malaysian Branch of the Royal Asiatic Society 37(2):162-174. Harrisson, Tom. 1973. The Minutti collections of bronzes in Brunei. Bandar Seri Begawan: Muzium Brunei.

Hein, A.R. 1889. Malerei und technische Künste bei den Dayaks. Annalen des

Kaiserlich-Königliches naturhistorischen Hofmuseum 4(3):197-288, and plates 9-18.

Hein, A.R. 1890. De bildende Künste bei den Dayaks auf Borneo: ein Beitrag zur allgemeinen Kunstgeschichte. Vienna: Alfred Hölder.

Heine-Geldern, Robert. 1966. Some tribal art styles of Southeast Asia: an experiment in art history. In The many faces of primitive art, ed. Douglas Fraser, 165-221. Englewood Cliffs: Prentice Hall.

Heppell, Michael, and Robyn Maxwell. 1990. Borneo and beyond: tribal arts of Indonesia, East Malaysia and Madagascar. Singapore: Bareo Gallery.

Heppell, Michael. 1988. Whither Dayak art? Sarawak Museum Journal 40(61), Special issue 4 (I):75-91.

Heppell, Michael. 1992. Masks of Kalimantan. Melbourne: Indonesian Arts Society.

Heppell, Michael. 1994. Whither Dayak art? In Fragile traditions: Indonesian art in jeopardy, ed.

Paul Michael Taylor, 123-138. Honolulu: University of Hawaii Press.

Heppell, Michael. 2005a. Iban art: sexual selection and severed heads. Amsterdam: KIT

Publishers.

Heppell, Michael. 2005b. Women's war: an update of the literature on Iban textiles. Moussons 8:143-153.

Heppell, Michael. 2011. Two curators: a classification of Borneo swords and some swords in the Sarawak Museum collection. Sarawak Museum Journal 68(89):1-40.

Heppell, Michael. 2014. The seductive warp thread: an evolutionary history of Ibanic weaving. Williamsburg, VA: Borneo Research Council.

Heppell, Michael. 2015 Communing with the dark side: Borneo masks and masquerades.

Williamsburg, VA: Borneo Research Council.

Hollestelle, Arjan. Forthcoming. Mandau: edged artworks from Borneo. n.p.

Hong, Evelyn. 1987. Natives of Sarawak: survival in Borneo’s vanishing forest. Penang: Institut Masyarakat Malaysia.

Hopes, Michael. 1997. Ilmu: magic and divination amongst the Benuaq and Tunjung Dayak. Jakarta: Puspa Swara and Rio Tinto Foundation.

Hose, C., and R. Shelford. 1906. Materials for a study of tatu in Borneo. Journal of the Royal Anthropological Institute 36:60-91.

Hose, Charles, and William McDougall. 1966 [1912]. The pagan tribes of Borneo. London: Frank Cass, 2 vols. [first publ. 1912, London: Macmillan].

Husna Asmara, U. et al. 1990-91. Dapur dan alat-alat memasak tradisional daerah Kalimantan

Barat. Pontianak: Departemen Pendidikan dan Kebudayaan, Proyek Inventarisasi dan

Pembinaan Nilai-nilai Budaya.

Huyser, J.G. 1929. Broenei en Broenei-bronzen. Nederlandsch-Indië Oud en Nieuw 14(2):34-49; 14(4):115-130. 
Ingold, Tim. 2000. The perception of the environment: essays on livelihood, dwelling and skill. London: Routledge.

Isler, Andreas, Paola von Wyss-Giacosa, and Wolfgang Marschall. 2011. Aufschlussreiches Borneo: Objekte, Fotografien und Dokumente des Schweizer Geologen Wolfgang Leupold in Niederländisch-Indien 1921-1927. Zürich: Völkerkundemuseum der Universität Zürich.

Jabu, Datin Paduka Empiang. 1991. Pua kumbu: the pride of the Iban cultural heritage. In Sarawak cultural legacy: a living tradition, eds. Lucas Chin, and Valerie Mashman, 75-89. Kuching: Society Atelier Sarawak.

Jakarta Post. 2012. A never-ending story of cultural disputes between Indonesia and Malaysia. Jakarta Post, 18 June.

Jamuh, George, and Tom Harrisson. 1966-69. Borneo cooking. Sarawak Museum Journal $14: 158-182 ; 17: 202-230$

Johnson, Mark A. 2009. Art of Borneo. Mark A. Johnson Gallery. n.p.

Journal of Material Culture. http://mcu.sagepub.com/.

Juynboll, H.H. 1910. Catalogus van 's Rijks Ethnografisch Museum, Borneo. Leiden: Brill, 2 vols. Kampffmeyer, Hanno. 1991. Die Langhäuser von Zentralkalimantan: Bericht einer Feldorschung. Munich: Anacon.

Kartiwa, Suwati. 1997. Sekilas budaya Kalimantan. Jakarta: Museum Nasional.

Kelbling, Sebastian. 1983. Longhouses at the Baluy River. Sarawak Museum Journal 32(53):133158.

King, Victor T. 1985. Symbols of social differentiation: a comparative investigation of signs, the signified and symbolic meanings in Borneo. Anthropos 80:125-152.

King, Victor T. 2012. Culture and identity: some Borneo comparisons. Bandar Seri Begawan:

Universiti Brunei Darussalam, Institute of Asian Studies, Working Papers Series 1.

King, Victor T., ed. 1994. Tourism in Borneo: issues and perspectives. Williamsburg, VA: Borneo Research Council, Proceedings Series 2.

Kjellgren, Eric. 1999. Guardians of the longhouse: art of the Kenyah-Kayan tradition. Tribal Arts 5 (4):52-60.

Klausen, Arne Martin. 1957. Basket-work ornamentation among the Dayaks. Studies honoring the centennial of the Universitetets Etnografiske Museum, 1857-1957, vol. 3. Oslo: Forenede Trykkerier.

Klokke, A.H. 1993. Description of a bamboo tube (solep) from central Borneo (Kalimantan) depicting Ngaju Dayak religious iconography. Sarawak Museum Journal 44(65):59-68.

Koninklijk Instituut voor de Tropen [KIT]. 2013. Tropenmuseum and Brunei Museum open exhibition during state visit. Amsterdam: Koninklijk Instituut voor de Tropen, 17 January.

Kooijman, Simon. 1963. Ornamented barkcloth in Indonesia. Leiden: Brill.

Kruse, William. 2003. Selling wild Borneo: a critical examination of the organised Iban longhouse tourism industry in Sarawak, East Malaysia. PhD thesis, Australian National University.

Kurui, Edmund, and Tuton Kaboy. 1989. Melanau ethno-arts and handicraft. Sarawak Museum Journal 40(61):251-57.

Leach, E.R. 1950. Social science research in Sarawak: a report on the possibilities of a social economic survey of Sarawak presented to the Colonial Social Science Research Council, London, March 1948-July 1949. London: His Majesty’s Stationery Office.

Lee Yong Leng. 1962. The long house and Dayak settlements in British Borneo. Oriental Geographer 6(1):39-60.

Leibrick, Fiona M. 1989. The power of objects: material culture's strategic importance to Orang Ulu ethnicity and the processes of social change. Sarawak Museum Journal 40(61), Special issue 4(3):199-213.

Lemonnier, Pierre. 1992. Elements for an anthropology of technology. Ann Arbor, MI: Museum of Anthropology.

Lenjau, Martin, Martua T. Sirait, and Bernard Sellato. 2012. Rattan and bamboo handicrafts of the Kenyah. In Plaited arts from the Borneo rainforest, ed. Bernard Sellato, 205-223. Honolulu: University of Hawaii Press.

Lenjau, Martin. 1999. Keragaman jenis kerajinan tangan dari rotan serta motif-motifnya di desa Long Alango. In Kebudayaan dan pelestarian alam: penelitian interdisipliner di pedalaman Kalimantan, eds. Cristina Eghenter and Bernard Sellato, 159-179. Jakarta: World Wide Fund for Nature.

Lim, J.S., and P.M. Shariffuddin. 1976. Brunei brass: the traditional method of casting. Brunei Museum Journal 3:142-166.

Lindell, Pamela N. 2000. The longhouse and the legacy of history: religion, architecture, and 
change among the Bisingai of Sarawak (Malaysia). PhD thesis, University of Nevada. Linggi, Datin Amar Margaret. 2001. Ties that bind: Iban ikat weaving. Kuching: Tun Jugah Foundation and Borneo Research Council.

Loebèr, J.A., Jr. 1903. Bamboeornament der KajanDajaks. The Hague: Vereeniging Oost en West.

Loebèr, J.A., Jr. 1918-1919. Bamboeornament van het eiland Borneo. Nederlandsch-Indië Oud en Nieuw 3:159-168, 189-202, 217-230.

Lumholtz, Carl S. 1991 [1920]. Through central Borneo: an account of two years' travel in the land of head-hunters between the years 1913 and 1917. Singapore: Oxford University Press [first publ. 1920, New York: Charles Scribner's Sons].

Maceda, Jose. 1978. Report of a music workshop in East Kalimantan. Borneo Research Bulletin 10(2):82-104.

Magai, Donata. 1991. Koleksi budaya masyarakat suku Daya Kendayan di Museum Negeri Kalimantan Barat. Pontianak: Departemen Pendidikan dan Kebudayaan, Proyek Pembinaan Permuseuman Kalimantan Barat.

Maiullari, Paolo, and Junita Arneld, eds. 2008. Patong: la grande scultura dei popoli del Borneo dalle Collezioni del Museo delle Culture di Lugano. Milan: Mazzotta.

Maiullari, Paolo, ed. 2011. Sapuyung: cappelli cerimoniali del Borneo. Milan: Mazzotta.

Marryat, Frank S. 1848. Borneo and the East Indian Archipelago. London: Longman, Brown, Green, and Longmans.

Martin, Petra. 2010. Das ‘Ost-Indische Museum’ des Oscar von Kessel (1812-1888).

Kontekstrecherchen zu einer frühen ethnographischen Sammlung. Jahrbuch des Staatlichen Kunstsammlungen Dresden 2010 36:130-141.

Mashman, Valerie. 1989. Ethnic arts and society: an Orang Ulu study. Sarawak Museum Journal 40(61), Special issue 4(3):215-227.

Mashman, Valerie. 1992. Warriors and weavers: a study of gender relations among the Iban of Sarawak. In Female and male in Borneo: contributions and challenges to gender studies, ed. Vinson H. Sutlive Jr., 231-270. Williamsburg, VA: Borneo Research Council.

Mashman, Valerie. 1994. Woodcarving in Sarawak: memory, meaning and mementoes. Sarawak Museum Journal 47(68):117-126.

Mashman, Valerie. 2000. Emblems for identity: ethnic costume, Catholicism and continuity: a Pinyawa'a Bidayuh study at Kampong Gayu. In Borneo 2000: ethnicity, culture \& society. Proceedings of the sixth biennial conference of the Borneo Research Council, ed. M. Leigh, 222-246. Kuching: Institute of South-East Asian Studies, University Malaysia Sarawak.

Mashman, Valerie. 2012. The baskets of the Kelabit at Long Peluan and their neighbors. In Plaited arts from the Borneo rainforest, ed. B. Sellato, 176-191. Honolulu: University of Hawaii Press.

Mashman, Valerie, and P. Nayoi. 2012. Body and soul: Bidayuh baskets at Kampong Gayu. In Plaited arts from the Borneo rainforest, ed. Bernard Sellato, 80-92. Honolulu: University of Hawaii Press.

Matusky, Patricia. 1986. Aspects of musical style among the Kajang, Kayan and Kenyah-Badang of the upper Rejang River: a preliminary survey. Sarawak Museum Journal 36(57):185-229.

Matusky, Patricia. 1990. Music styles among the Kayan, Kenyah Badang and Malay peoples of the upper Rejang River (Sarawak): a preliminary survey. Sarawak Museum Journal 41(62):115149.

Matusky, Patricia. 1991. Musical instruments of Sarawak. In Sarawak cultural legacy: a living tradition, eds. Lucas Chin, and Valerie Mashman, 217-230. Kuching: Society Atelier Sarawak. Maxwell, J.R. 1980. Textiles of the Kapuas basin. In Indonesian textiles: Irene Emery Roundtable on museum textiles 1979 proceedings, ed. Mattiebelle Gittinger, 127-140. Washington, DC: Textile Museum.

McBain, Audrey. 1981a. Shang and Chou influences observed in the ethnic art of Borneo. Brunei Museum Journal 5(1):19-32.

McBain, Audrey. 1981b. Borneo tattoo design. Arts of Asia, January-February:123-130.

Metcalf, Peter. 1976. Berawan mausoleums. Sarawak Museum Journal 24(45):121-136.

Metcalf, Peter. 2010. The life of the longhouse: an archaeology of ethnicity. New York:

Cambridge University Press.

Miles, Douglas. 1964. The Ngadju longhouse. Oceania 35(1):45-57.

Mohd. Kassim Haji Ali. 1983. Masks of Sarawak in the collection of the Muzium Negara

Malaysia. Kuala Lumpur: Muzium Negara, Museum Association of Malaysia.

Morris, Stephen. 1953. Report on a Melanau sago producing community in Sarawak. London: Her 
Majesty's Stationery Office.

Morrison, Hedda. 1948. Maloh silversmiths in Sarawak. Geographical Magazine 21:249-255.

Morrison, Hedda. 1972. Tribal crafts of Borneo. Arts of Asia 2(1):60-66.

Morrison, Hedda. 1982. Craftsmen in a harsh environment. Arts of Asia 12(2):87-95.

Morrison, Hedda. 1988 [1962]. Life in a longhouse. Singapore: Summer Times.

Mulyati Tahir and Zularfi. 1994. Benda-benda koleksi etnografika berupa wadah yang terbuat

dari tumbuh-tumbuhan. Tenggarong: Departemen Pendidikan dan Kebudayaan, Museum

Negeri Propinsi Kalimantan Timur Mulawarman.

Munan, Heidi. 1989a. Sarawak crafts: methods, materials, and motifs. Singapore: Oxford

University Press.

Munan, Heidi. 1989b. Sarawak handicrafts: the economic aspect. Sarawak Museum Journal 40 (61):117-125.

Munan, Heidi. 2005. Beads of Borneo. Singapore: Editions Didier Millet.

Munan-Oettli, Adelheid. 1987. Blue beads to trade with the natives. Arts of Asia 17(2):88-95.

Münsterberger, W. 1939. Die Ornamente an DayakTanzschilden und ihre Beziehung zu Religion und Mythologie. Cultureel Indië 1:337-343.

Needham, Rodney. 1953. The social organisation of Penan, a Southeast Asian people. PhD thesis, Oxford University.

Nicolaisen, Ida, and Tinna Damgaard-Sörensen. 1991. Building a longboat, Roskilde: Viking Ship Museum.

Nieuwenhuis, Anton Willem. 1904-07. Quer durch Borneo: Ergebnisse seiner Reisen in den Jahren 1894, 1896-97, und 1898-1900. Leiden: Brill, 2 vols.

Nieuwenhuis, Anton Willem. 1925-26. Kunst van Borneo. Nederlandsch-Indië Oud en Nieuw 10:67-92.

Okezone. 2013. Tikar bidai diklaim Malaysia, pemerintah dinilai tak cerdas. http://news.okezone. com/read/2013/12/27/340/918209/tikar-bidai-diklaim-malaysia-pemerintah-dinilai-tak-cerdas. Oley, Elizabeth. 2001. Benuaq textiles of East Kalimantan. The impact of cultural tourism on their revival. Postgraduate diploma, University of Melbourne.

Oley, Elizabeth. 2007. Ulap Doyo: woven fibers of East Kalimantan. In Material choices: refashioning bast and leaf fibers in Asia and the Pacific, eds. Roy W. Hamilton, and B. Lynne Milgram, 62-78. Los Angeles: Fowler Museum at UCLA.

Ong, Edric. 1991. Architecture. In Sarawak cultural legacy: a living tradition, eds. Lucas Chin, and Valerie Mashman, 231-244. Kuching: Society Atelier Sarawak.

Ong, Edric. n.d. [2000?]. Woven dreams: Ikat textiles of Sarawak. Kuching: Society Atelier Sarawak.

Perelaer, M.T.H. 1870. Ethnographische beschrijving der Dajaks. Zaltbommel: J. Noman. Piper, Jacqueline M. 1992. Bamboo and rattan: traditional uses and beliefs. Singapore: Oxford University Press.

Pugh-Kitingan, Jacqueline. 1988. Instruments and instrumental music of the Tambunan Kadazan/Dusun. Sabah Museum and Archives Journal 1(2):24-61.

Puri, Rajindra K. 2006. Deadly dances in the Bornean rainforest: hunting knowledge of the Penan Benalui. Leiden: KITLV Press.

Puri, Rajindra K. 2013. Transmitting Penan basketry knowledge and practice. In Understanding cultural transmission in anthropology: a critical synthesis, eds. Roy Ellen, Stephen J. Lycett, and Sarah E. Johns, 440-501. Oxford: Berghahn.

Rampai, Kiwok D. 1983. Bangunan makam orang Ngaju di Kalimantan Tengah. Suatu studi ethno-arkeologi. Thesis, Universitas Gadjah Mada.

Rangkuti, Nurhadi, and Mindra Faizaliskandiar, eds. 1988. Naga Singkawang: tradisi pembuatan keramik kuno yang tersisa di Indonesia. Jakarta: Bentara Budaya, Ikatan Ahli Arkeologi Indonesia and Himpunan Keramik Indonesia.

Rasmin et al. 1992-93. Katalog koleksi Museum Negeri Provinsi Kalimantan Barat. Pontianak: Departemen Pendidikan dan Kebudayaan, Proyek Pembinaan Permuseuman.

Rassers, W.H. 1928-29. Naar aanleiding van eenige maskers van Borneo. Nederlandsch-Indië

Oud en Nieuw 13(2):35-64.

Regis, Patricia 1996. Aspects of indigenous material culture change and adaptation in Sabah, 1982-1994. Paper presented at the Fourth Biennial International Conference of the Borneo Research Council, Bandar Seri Begawan, Brunei Darussalam.

Remešová, Blanka M. 2004. Dayaks' art: tribal art from the Indonesian collections of the Náprstek Museum, Prague. Annals of the Náprstek Museum 25:17-28.

Revel-Macdonald, Nicole. 1978. La danse des hudoq (Kalimantan Timur). Objets et Mondes 18 
$(1 / 2): 31-44$

Revel-Macdonald, Nicole. 1981. Masks in Kalimantan Timur. The World of Music 23(3):52-57.

Roth, Henry L. 1968 [1896]. The natives of Sarawak and British North Borneo. Singapore:

University of Malaya Press, 2 vols.

Rousseau, Jérôme. 1990. Central Borneo: ethnic identity and social life in a stratified society.

Cambridge: Clarendon Press.

Rutter, O. 1985 [1929]. The pagans of North Borneo. Singapore: Oxford University Press [first publ. 1929, London: Hutchinson].

Sabah. 1991. Bengkel anyaman/tenunan dan pewarnaan tradisional. Traditional weaving and dyeing workshop. Kota Kinabalu: Sabah Museum.

Sabah. 1992. Sabah's heritage: a brief introduction to Sabah's heritage. Pengenalan ringkas sejarah dan warisan Sabah. Kota Kinabalu: Sabah Museum.

Sabah. 2007. Sabah Museum ceramic gallery. CD-ROM, vol. 1. Kota Kinabalu: Sabah Museum. Sabah. n.d. Rumah tradisional etnik Sabah. Kota Kinabalu: Sabah Museum.

Sather, Clifford. 1993. Posts, hearths and thresholds: the Iban longhouse as a ritual structure. In Inside Austronesian houses: perspectives on domestic designs for living, ed. James J. Fox, 64115. Canberra: Australian National University, Research School of Pacific Studies.

Schärer, H. 1940-41. Maskers op Borneo. Wolanda Hindia 14:31-34.

Schiller, Anne L. 1984. Monumen kematian Dayak Ngaju dahulu dan sekarang. Kalimantan Scientiae 8:45-61.

Schneeberger, W.F. 1979. Contributions to the ethnology of central northeast Borneo (parts of Kalimantan, Sarawak and Sabah). Bern: University of Bern, Studia Ethnologica Bernensia 2. Schwaner, C.A.L.M. 1853-54. Borneo: beschrijving van het stroomgebied van den Barito en reizen langs eenige voor-name rivieren van het zuid-oostilijk gedeelte van dat eiland.

Amsterdam: P.N. Van Kampen, 2 vols.

Seeler, Joan DeWitt 1969. Some notes on traditional dances of Sarawak. Sarawak Museum Journal 17(34-35):163-201.

Sekelumit. 1989-90. Sekelumit koleksi Museum Negeri Kalimantan Tengah. Palangkaraya: Departemen Pendidikan dan Kebudayaan, Proyek Pembinaan Permuseuman Kalimantan Tengah.

Sellato, Bernard. 1989. Hornbill and dragon (Naga dan burung enggang): Kalimantan, Sarawak, Sabah, Brunei. Jakarta and Kuala Lumpur: Elf Aquitaine.

Sellato, Bernard. 1992. Hornbill and dragon: arts and culture of Borneo. Singapore: Sun Tree. Sellato, Bernard. 1997. Traditional handicrafts. In People and plants of Kayan Mentarang, eds. Kim Worm Sørensen, and Belinda Morris, 229-240. London: World Wide Fund for Nature and UNESCO.

Sellato, Bernard. 1998. Modern architecture and provincial identity in Kalimantan. In Indigenous architecture in Borneo: traditional patterns and new developments, ed. Robert L. Winzeler, 198-234. Williamsburg, VA.: Borneo Research Council, Proceedings Series 5.

Sellato, Bernard. 2001. High status markers in low relief: carved doors and panels of Borneo. Arts \& Cultures 2:136-155.

Sellato, Bernard. 2006. Bark-clothes in East Kalimantan. In Bark-cloth in Southeast Asia, ed. Michael C. Howard, 153-168, 260-263. Bangkok: White Lotus, Studies of the Material Culture of Southeast Asia.

Sellato, Bernard. 2012a. Plaitwork of the Kelabit-Kerayan high plateau. In Plaited arts from the Borneo rainforest, ed. Bernard Sellato, 192-204. Honolulu: University of Hawaii Press.

Sellato, Bernard. 2012b. The baby carrier: a Central Borneo specialty. In Plaited arts from the Borneo rainforest, ed. Bernard Sellato, 272-281. Honolulu: University of Hawaii Press. Sellato, Bernard. 2012c. Kenyah sun hats. In Plaited arts from the Borneo rainforest, ed. Bernard Sellato, 224-232. Honolulu: University of Hawaii Press.

Sellato, Bernard, ed. 2012d. Plaited arts from the Borneo rainforest. Honolulu: University of Hawaii Press.

Sellato, Bernard. 2015a. Sultans' palaces and museums in Indonesian Borneo: national policy, political decentralization, cultural depatrimonization, identity relocalization, 1950-2010.

Archipel 89:125-160.

Sellato, Bernard. 2015b. Crafts, culture, and economics, between resilience and instability: borrowing from and trading to farmers among Borneo's nomads. In The arts of hunter-gatherers: collecting, crafting, constructing, ed. Lye Tuck-Po. Hunter-Gatherer Research 1(2):157-195.

Shelford, R. 1901. A provisional classification of the swords of the Sarawak tribes. Journal of the 
Royal Anthropological Institute 31:219-228.

Shelford, R. 1904-1905. An illustrated catalogue of the ethnographical collections of the Sarawak

Museum. Journal of the Straits Branch of the Royal Asiatic Society 40:1-59, 43:1-67.

Sjarifuddin. 1983-84. Anyaman rotan tradisional Margasari. Banjarmasin: Departemen

Pendidikan dan Kebudayaan, Direktorat Permuseuman, Museum Negeri Lambung

Mangkurat, Propinsi Kalimantan Selatan, Seri Penerbitan Khusus, 4.

Sloan, C. 1975. A study of the Punan Busang, III: Punan hunting methods. Malayan Nature Journal 28(3/4):146-151.

Soenarpo S.H., Sugiyarto Dakung, and Rifai Abu. 1986. Arsitektur tradisional daerah Kalimantan

Barat. Jakarta: Departemen Pendidikan dan Kebudayaan, Proyek Inventarisasi dan

Dokumentasi Kebudayaan Daerah.

Sørensen, Steinar. 1972. Signs and symbolism of message-sticks from the Katingan Ngadju in

south Borneo. In Ethnographic Museum, University of Oslo, Yearbook 1970, 65-75. Oslo:

Universitetsforlaget.

Sørensen, Steinar. 1973. Slangen, fuglen og livets tre: form og mening i Ot

Danum-Ngadyudayakenes representative ornamentikk. Magister thesis, University of Oslo.

St John, Spenser. 1986 [1862]. Life in the forests of the Far East: travels in Sarawak and Sabah in the 1860s. Singapore: Oxford University Press, 2 vols. [first publ. 1862, London: Smith, Elder

$\& \mathrm{Co}]$.

Sumnik-Dekovich, Eugenia. 1985. The significance of ancestors in the arts of the Dayak of Borneo. In The eloquent dead: ancestral sculpture of Indonesia and Southeast Asia, ed. Jerome Feldman, 101-128. Los Angeles: UCLA Museum of Cultural History.

Surya Yoga et al. 1985-86. Peralatan produksi tradisional dan perkembangannya di daerah Kalimantan Timur. Samarinda: Departemen Pendidikan dan Kebudayaan, Direktorat Sejarah dan Nilai Tradisional, Proyek Inventarisasi dan Dokumentasi Kebudayaan Daerah.

Sutlive, Vinson H., and Joanne Sutlive, eds. 2001. The encyclopaedia of Iban studies: Iban history, society and culture. Kuching: Tun Jugah Foundation, 4 vols.

Syarifuddin and M. Saperi Kadir. 1990-91. Mengenal koleksi Museum Negeri Propinsi

Kalimantan Selatan Lambung Mangkurat. Banjarbaru: Departemen Pendidikan dan

Kebudayaan, Proyek Pembinaan Permuseuman Kalimantan Selatan.

Taihuttu, Charles J. 1995-96. Penginangan dalam kehidupan masyarakat Kalimantan Timur.

Tenggarong: Departemen Pendidikan dan Kebudayaan, Bagian Proyek Pembinaan

Permuseuman.

Taylor, Paul Michael, and Lorraine V. Aragon. 1991. Beyond the Java Sea: art of Indonesia's outer islands. Washington, DC: National Museum of Natural History.

Taylor, Paul Michael, ed. 1994. Fragile traditions: Indonesian art in jeopardy. Honolulu: University of Hawaii Press.

Teuteberg, Sabina. 1998. Talking clay with the Kelabits of Bario highlands, Sarawak. In A scientific journey through Borneo: Bario: the Kelabit highlands of Sarawak, eds. Ghazally Ismail and Laily bin Din, 343-352. Kuala Lumpur: Pelanduk.

Thambiah, Shanthi. 1995. Culture as adaptation: change among the Bhuket of Sarawak, Malaysia. PhD thesis, University of Hull.

Thomas, Sharon. 1968. Women's tattoos of the upper Rejang. Sarawak Museum Journal 16:209234.

Tillema, H.F. 1930. Tatoeëeren op Borneo. Nederlandsch-Indië Oud en Nieuw 15(7):193-208.

Tillema, H.F. 1931-32. Doodenpalen, tiwah en lijkverbranding op Borneo. Nederlandsch-Indië Oud en Nieuw 16:131-156.

Tillema, H.F. 1937. Religion in eggs, stones and masks. The Netherland Mail 4(4):87-90.

Tillema, H.F. 1938. Apo-Kajan: een filmreis naar en door Centraal-Borneo. Amsterdam: Van Munster.

Tillema, H.F. 1939. Merkwaardig vlechtwerk der Dajaks. Natuur en Techniek 9(1):31-34.

Tillmann, G. 1939. Bijdrage tot het kapittel Broenei-bronzen, Cultureel Indië 1:217-226.

Tillotson, Dianne Margaret. 1994. Who invented the Dayaks? Historical case studies in art, material culture and ethnic identity from Borneo. PhD thesis, Australian National University. Tiong Tak Liong. 2001. The changing faces of Sarawak: pictures of local photographer Soon Lee Guan. Sibu: Photography Society of Sibu.

Tromp, S.W. 1888. Mededeelingen omtrent mandau's. Internationales Archiv für Ethnographie 1:22-26.

Tromp, S.W. 1890. De kleeding eener Dajaksche vrouw. Internationales Archiv für Ethnographie $3: 1-6$. 
Veth, P.J. 1854-56. Borneo's Westerafdeeling, geographisch, statistisch, historisch, voorafgegaan door eene algemeene schets des ganschen eilands. Zaltbommel: Joh. Noman en Zoon, 2 vols. Vogelsanger, C. 1980. A sight for the gods: notes on the social and religious meaning on Iban ritual fabrics. In Indonesian textiles, ed. Mattiebelle Gittinger, 115-126. Washington, DC:

Textile Museum.

Vredenbregt, Jacob. 1981. Hampatong: the material culture of the Dayak of Kalimantan.

Kebudayaan material suku Dayak di Kalimantan. Jakarta: Gramedia.

Vroklage, B.A.G. 1939. The ship in the megalithic cultures of Indonesia (Borneo and Java). The Netherland Mail 6:56-59, 110-114.

Warisan. 1996. Warisan budaya: kain tenun (motif dan bunga). Bandar Seri Begawan: Jabatan Muzium Brunei, Special Publication 25.

Waterson, Roxana. 1990. The living house: an anthropology of architecture in South-East Asia. Singapore: Oxford University Press.

Westmacott, Karen. 2002. Christ is the head of the house: material culture and new modes of consumption for the Kayan in the 1990s. PhD thesis, Australian National University.

Whitehead, John. 1893. Exploration of Mount Kina Balu, North Borneo. London: Gurney \& Jackson.

Whittier, Herbert L. 1973. Social organization and symbols of social differentiation: an ethnographic study of the Kenyah-Dayak of East Kalimantan (Borneo). PhD thesis, Michigan State University.

Whittier, Herbert L., and Patricia R. Whittier. 1974. Some Apo Kayan megaliths. Sarawak Museum Journal 22(43):369-381.

Whittier, Herbert L., and Patricia R. Whittier. 1988. Baby carriers: a link between social and spiritual values among the Kenyah Dayak of Borneo. Expedition 30(1):51-58.

Wibisono, Naniek H. 1990. Keramik Singkawang: sisa-sisa teknologi kuno. Saraswati. Esai-esai arkeologi, Kalpataru 9:136-146.

Winzeler, Robert L. 1996. Bidayuh architecture: tradition, change, revival. Sarawak Museum Journal 50(71):1-23.

Winzeler, Robert L. 1999. Notes on two engraved half-skulls in Kampung Grogo, Bau. Sarawak Museum Journal 54(75):201-209.

Winzeler, Robert L. 2004. The architecture of life and death in Borneo. Honolulu: University of Hawaii Press.

Winzeler, Robert L., ed. 1998. Indigenous architecture in Borneo: traditional patterns and new developments. Williamsburg, VA.: Borneo Research Council, Proceedings Series 5.

Wong, K.F. 1979. Borneo scene. With an introduction by Malcolm MacDonald, Kuching: Anna Photo Co.

Woolley, G.C. 1929. Some notes on Murut basketwork and patterns. Journal of the Malayan Branch of the Royal Asiatic Society 7(2):291-315.

Zainie, Carla. 1969. Handcraft in Sarawak. Kuching: Borneo Literature Bureau.

Zeppel, Heather. 1994. Authenticity and the Iban: cultural tourism at Iban longhouses in Sarawak, East Malaysia. PhD thesis, James Cook University. 